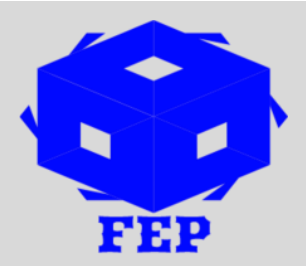

\title{
PREDICTION OF TAX AVOIDANCE BEHAVIOR AMONG TRANSPORTATION AND LOGISTIC SECTOR FIRMS IN BRAZIL
}

\author{
Nelson Kalil ${ }^{1}$ \\ ${ }^{1}$ Federal University of Curitiba, Brazil
}

*Corresponding Author: Nelson Kalil

Article Received: 18-05-19

Accepted: 25-09-19

Published: 25-10-19

Licensing Details: Author retains the right of this article. The article is distributed under the terms of the

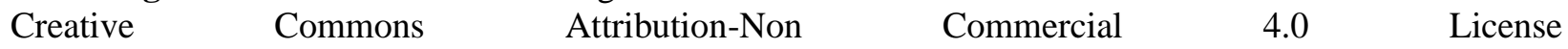
(http://www.creativecommons.org/licences/by-nc/4.0/) which permits non-commercial use, reproduction and distribution of the work without further permission provided the original work is attributed as specified on the Journal open access page.

\section{ABSTRACT}

The study was focused towards investigation of corporate mechanisms on tax avoidance behavior of corporations. The study objective was to measure the effects of corporate governance mechanism on tax avoidance behavior of rims. Sector wise, the study focused on transportation and logistic sector in Brazil. The methodology was quantitative and data was from 2012 to 2017 from 18 selected firms listed in the stock exchange. Regression analysis is used for testing the hypothesis. The indicator of corporate governance included independent commissioner, managerial ownership, institutional ownership, size of directors, audit committee, liquidity, and company size. Findings shows that there is significant negative effects of institutional ownership and audit committee on firm tax avoidance behavior. These findings imply that there must be a strong audit committee and institutional ownership in order to avoid negative financial behavior by corporates in this particular sector.

Keywords: Tax Avoidance, Corporate Mechanism, Audit, Transportation, Logistic, Brazil

\section{INTRODUCTION}

Brazilian Government pass new legislation related to tax in order to improve the corporate sector in the country. This law enabled companies to get reduction in taxes. It is safe to assume that for corporate sector, the tax is highly important matter as most companies involves in tax planning, tax avoidance, and tax evasion. Tax is a source of income for a country and important for its 
development; however, companies see tax as a burden. In this study, the focus is on transportation and logistics companies which were burdened by heavy taxes in the country. The transportation and logistics companies face tax problems as heavy taxes, complicated procedures, and coercive behavior of tax department and officials. One way companies can overcome these problems using good corporate governance mechanisms. In this study, the central theme is to understand the relationship between corporate governance mechanism and tax avoidance. The objectives of the study are as follows;

- To test the effects of corporate governance mechanism on tax avoidance.

The sub-objectives of the study are as follows;

- To test the effects of independent commissioner on tax avoidance.

- To test the effects of managerial ownership on tax avoidance

- To test the effects of institutional ownership on tax avoidance

- To test the effects of size of directors on tax avoidance

- To test the effects of audit committee on tax avoidance

- To test the effects of liquidity on tax avoidance

- To test the effects of company size on tax avoidance

\section{Study Significance}

The significance of this study is that it investigates the tax avoidance in the transportation and logistics companies in Brazilian context. Similar studies are conducted in other countries but not in Brazil, this is a literature gap which this study intends to fulfill. The findings can be used by companies to avoid negative financial practices such as tax avoidance as it provides useful guideline about it.

\section{LITERATURE REVIEW}

\section{Corporate Governance}

Corporate governance is a system which regulate the relationships between the board of directors, commissioners, management, and other key stakeholders of the company (Sastriana, 2013). There are three main dimensions of corporate governance mechanisms including ownership structure, independent commissioners, and audit committee. Their details are given below;

\section{Ownership Structure}

Ownership structure is the proportion between managerial ownership (inside) and institutional ownership (outside) (Jusup, 2005). The institutional ownership is the ownership of shares by other companies or institutions such as investment companies, insurance companies, and asset management or ownership type of institutions (Al-Najjar \& Taylor, 2008). The ownership structure is measured by on the shares possessed by management in relation to the total outstanding shares. Institutional ownership is a measure of how many shares are owned by other institutions compared to the total outstanding shares. 


\section{Board of Director Size}

Board of director size means the number of directors in a corporate board (Destriana \& Arifin, 2016). Generally, a board consist of several members from diverse fields and has the authority to set the long term policy and strategic direction of a company.

\section{Board of Commissioners}

The board of commissioners refers to the such board members who are responsible for overseeing the management performance but do not involve in any managerial tasks (FCGI, 2001). The board of commissioners normally do not involve in any managerial task and do not represent the company in any third party transaction.

\section{Audit Committee}

Audit committee in corporate world is a committee which is responsible for supervising the audit function of the organization (FCGI, 2001). The job of audit committee is to advice board of commissioners regarding any issues related to the audit of the company. The audit committee may consist of various number of members but mostly these individuals possess the accounting, finance, and auditing background.

\section{Liquidity}

The liquidity ratio is a useful tool in understanding a company's financial condition or strength. It is an indicator of how well a company meet its short term obligation (Endriati, Nur, \& Junaidi, 2013). In other words, if a company possess enough short term liquid assets so it will be quickly able to pay its short term liabilities and will not be in risky situation where it cannot fulfill its short term obligations. This measure also indicate a company ability to fulfill its short term obligations such as short term creditors. The benefit of a good liquidity ratio is that it enable company to fulfill its short term obligations without any risk to its functionality.

\section{Company Size}

Company size is also an important variable in term of tax evasion. A company with small size find it difficult to access creditors since its transaction cost is increased. A firm size can be linked with its total assets utilizing the logarithmic value as suggested by Casssar and Holmes (2003). The present study also utilize this approach of measuring the firm size by the logarithm of its total assets.

\section{Tax Evasion}

Tax avoidance or evasion is about efforts of a company management to make less payment in terms of tax liabilities using some proper management of its financial aspects and identification and utilization of some loopholes in the tax system of a country (Sophar, 2008). In other words, tax avoidance is a method of tax planning to legally reduce the income tax paid. Usually, it can be done using some modification in financial statements such as showing less sales, less income, showing higher expenditures and so on. 


\section{RESEARCH DESIGN}

The method used in this study is quantitative. It is also cross-sectional research design since it checks the effects of independent variables including corporate governance, liquidity and company size mechanism on tax avoidance. The data used in this study is secondary data which is collected from Stock Exchange for a period of 5 years.

\section{Population \& Sampling}

The population is all transportation and logistics companies listed in the Brazilian Stock Exchange. The sampling is based on non-random sampling. Through sampling, we selected 18 companies listed in the stock exchange and related to the logistics and transportation companies. and period of data collection is from 2012 to 2017.

\section{Method of Analysis}

The data once collected is checked for errors and entered in Excel sheet. The tool for analysis was SPSS version 21 and the technique for analysis included descriptive statistics and regression analysis.

\section{RESEARCH RESULTS}

Research results are provided below.

Table 1

\section{Descriptive Statistics}

\begin{tabular}{lcccc}
\hline & Min & Max & Mean & S.D. \\
\hline Independent Commissioner & 15 & 77.77 & 51.33 & 9.75 \\
Managerial Ownership & 0.00 & 0.11 & 0.012 & 0.0528 \\
Institutional Ownership & 14 & 89 & 1.23 & 0.252 \\
Size of Directors & 1.0 & 8.0 & 5.123 & 0.854 \\
Audit Committee & 3.0 & 4.0 & 4.431 & 0.278 \\
Liquidity & 0.00 & 7.01 & 0.7716 & 0.524 \\
Company Size & 9.11 & 17.77 & 14.0318 & 1.002 \\
Tax Avoidance & -0.58 & 0.55 & 0.543 & 0.205 \\
\hline
\end{tabular}

The independent commissioner mean value is 51.33 . The managerial ownership is only moderate with mean value of 0.012 . The institutional ownership mean value is only moderate with 1.23. The size of director is average 5.123. The audit committee average size is 4.431 . The liquidity average is 0.7716 . The tax avoidance mean value is 0.543 means there is moderate level of tax avoidance reported.

Table 2

\begin{tabular}{lccc}
\multicolumn{1}{c}{ Regression Results } & & & \\
\hline \multicolumn{1}{c}{ Variable } & Beta & t-stat & Sig. \\
\hline Constant & -0997 & & \\
Independent Commissioner & .006 & 1.546 & 0.127 \\
Managerial Ownership & .615 & 1.233 & .222 \\
Institutional Ownership & -.311 & -1.908 & .049 \\
Size of Directors & .037 & 1.838 & .071 \\
Audit Committee & -.611 & -3.057 & .003 \\
Liquidity & -.0101 & -.699 & .487 \\
Company Size & -.011 & -1.189 & .239 \\
& & & \\
\hline
\end{tabular}


The result shows that there are insignificant effects of independent commissioner on tax avoidance with beta value of .006 and significance value of .127. There are insignificant effects of managerial ownership on tax avoidance with beta value of .615 and significance value of .222. there are negative and significant effects of institutional ownership on tax avoidance with beta value of -.311 and significance value of .049. there are positive and significant effects of audit committee on tax avoidance with beta value of .611 and significance value of .003. There are negative and insignificant effects of liquidity on tax avoidance with beta value of -.0101 and significance value of .487 . There are insignificant and negative effects of company size on tax avoidance with beta value of -.011 and significance value of .239. From these results, it is clear that most important factors which influence on tax evasion are audit committee which reduce tax avoidance in the company.

\section{Discussion}

The objective of this study is to test the influence of various corporate governance mechanisms on tax avoidance which is not good for the organization and the country. Tax avoidance is not good for the company because in the long term, it distorts its reputation and create problems. Similarly, it is not good for the country and its economy since it reduces tax collection and less money available for the developmental purpose. In present study, we looked in to the effects of different corporate governance mechanism on tax avoidance in the transport and logistic company in the Brazil. The factors which we used for corporate governance included independent commissioner, managerial ownership, institutional ownership, size of directors, audit committee, liquidity, and company size. The results showed that most of the governance mechanism have insignificant effects on corporate tax avoidance. The significant factors are institutional ownership and audit committee. Because of the very nature, it is generally logical connection between presence of good audit committee and tax avoidance since audit can help mitigating such negative practices. Institutional ownership on the other hand is about other companies holding major shares of a company. The benefit of such institutional investment in a company is that it helps in improving its governance mechanism and better influence on governance processes.

\section{CONCLUSION}

The focus of the study was to test the influence of different indicators of a corporate governance mechanism on company's tax avoidance. Focus of the study remained the transportation and logistics companies in the Brazil The secondary data on each variable is collected from the selected companies listed in the Stock Exchange. The regression analysis is used for analysis purpose. Results showed that independent commissioner, managerial ownership, size of directors, liquidity, and company size are insignificantly related with company's tax avoidance. The two factors including institutional ownership and audit committee are having negative and significant effects on company tax avoidance. In other words, a good institutional ownership and 
audit committee can reduce the problem of tax avoidance in a company.

\section{Recommendations}

The first main recommendation is that a company should not avoid tax as such practices can lead to the long term damage to its reputation. Further, it can also put company at risk of future litigation process and fines from the tax authorities.

Second recommendation is that the transportation and logistics companies in Brazil should develop a strong audit committee. Such committee can help in reducing the negative financial practices within an organization.

\section{Limitations}

The limitation is small sample and focus on single sector. Due to the time and financial constraints, small sample size is also our constraint.

\section{Acknowledgement}

The authors are thankful to the management of the Federal University of Curitiba, Brazil, for providing support for completing this study.

\section{Declaration of Conflict of Interest}

The author declares no conflict of interest.

\section{References}

Al-Najjar, B., \& Taylor, P. (2008). The relationship between capital structure and ownership structure: New evidence from Jordanian panel data. Managerial Finance, 34(12), 919933

Cassar, G., dan Holmes, S. (2003). Capital Structure and Financing of Smes: Australian Evidence. Journal of Accounting and Finance, 43, 123-147

Destriana, M., Dan Arifin, L.(2016) Effect of Firm Size Corporate Governance and Corporate Characteristics on Earnings Management. Journal of Business and Accounting, 18, 84-93

Endriati, Enny., Hidayati, Nur., \& Junaidi. (2013). The Effect of Tax Planning on Profit Management in Non-Manufacturing Companies Listed on the Indonesia Stock Exchange. Jurnal Universitas Islam Malang

Haryono, Jusup. (2005). Accounting Basics. Issue 6. Yogyakarta: Penerbit Sekolah Tinggi Ilmu Ekonomi YKPN

Lumbantoruan, Sophar. (2008). Tax Accounting. Jakarta: Grasindo

Sastriana, D.F. (2013). The Effect of Corporate Governance and Firm Size on Companies experiencing (Financial Distress). Diponegoro Journal of Accounting, 3, 1-10 